\title{
Determination of Stresses and Displacements in Rigid Pavement Slabs, Through Finite Element Analysis
}

\author{
Fernando Jove Wilches*1, Carlos Millán-Páramo ${ }^{1}$ and Álvaro Rafael Caballero Guerrero \\ ${ }^{1}$ Department of Civil Engineering, Universidad de Sucre, Sincelejo, Sucre, Colombia. \\ ${ }^{2}$ Department of Civil and Environmental Engineering, Universidad del Norte, Barranquilla, Colombia.
}

ORCIDs: 0000-0002-2080-4036 (Fernando), 0000-0002-0004-6063 (Carlos), 0000-0002-3567-9135 (Álvaro)

\begin{abstract}
In this work, the results of the structural modelling of several structures of rigid pavements are presented, consisting of a concrete slab in thicknesses of $10,15,20,25$ and $30 \mathrm{~cm}$, supported by a granular base layer of $20 \mathrm{~cm}$ of thickness and this in turn, supported on a material selected to improve the subgrade, in the thicknesses necessary to obtain a level of bearing capacity of the improved subgrade, in terms of its CBR $=5 \%$. For this modelling, the EverFE finite element program was used, through which some interesting relationships could be determined between the thickness of the slab and the stresses and deflections generated, as the structural packages were subjected to four types of loaded axles with the maximum legal loads per axle established in Colombia: steering axles, with a load of 6 tons; single axles with double wheels, with a load of 11 tons; tandem axles, with a load of 22 tons and tridem axles, with a load of 24 tons.
\end{abstract}

Keywords: Rigid pavement, finite elements, stresses, deflections, axle loads

\section{INTRODUCTION}

Rigid pavements can be used for the adaptation of the surface layer of projects such as urban roads, parking lots, industrial yards, roads for the exploitation of mines or airports. In Colombia, concrete pavements have become a good alternative for paving roads and have provided a service with very good performance for many years [1].

A rigid pavement is made up of a hydraulic concrete slab, supported directly on the subgrade or on a layer of selected material called the base. The fundamental element of the pavement is a slab of hydraulic concrete, which distributes the loads of the vehicles towards the lower layers, and produces a good distribution of the loads, resulting in very low stresses in the support layers [2]. This slab also serves as a rolling layer for vehicular traffic and must withstand environmental effects, to ensure the durability of the work during its service period.

The Portland Cement Association classifies rigid concrete pavement types into three main groups, based on joint spacing and arrangement of reinforcement in slabs: Jointed Reinforced
Concrete Pavement (JRCP), Continuously Reinforced Concrete Pavement (CRCP) and Jointed Plain Concrete Pavement (JPCP) [3]. The present study focuses on JPCP pavements, which contain enough joints to control the location of all the expected natural cracks, in this way, all the necessary cracks occur in the joints and not in other parts of the slabs. JPCP does not contain any steel reinforcement; however, there may be load transfer devices at transverse joints, called dowels, and steel bars at longitudinal joints [4].

Rigid pavements must be analyzed with the plate theory, instead of the elastic layer theory, due to the high rigidity of concrete slabs and also to the presence of discontinuities (joints and cracks) in them [5]. For the analysis of this type of pavement, the finite element method can be applied, which offers great versatility to model, analyze and design these structures, because multiple variables can be considered, in addition to traffic, as is the case of thermal processes, interaction with the support layer, load transfer through aggregates or the use of segments, among others [6]. Currently, there are many tools that are based on finite element theory and many of them are freely accessible, such as the EverFE [7] software.

The purpose of this work is to carry out the modeling of rigid pavement structures, through the finite element method, considering the main configurations of load axles for use in Colombia. The modeling is performed using the $3 \mathrm{D}$ finite element tool, EverFE, considering for this purpose, pavement slab structures with thicknesses of 100, 150, 200, 250 and 300 $\mathrm{mm}$, supported on a granular base of $20 \mathrm{~cm}$ of thickness, which was supported in turn, on an improved soil that simulates the typical conditions of the subgrade soils of the study area. In total, four typical load axles were analyzed: steering axles, with a 6-ton load; single axles with double wheels, with a load of 11 tons; tandem axles, with a load of 22 tons and tridem axles, with a load of 24 tons. From the modeling carried out, the stress and displacements could be obtained, both graphically and numerically. 


\section{MATERIALS AND METHODS}

\section{II.I Finite element analysis with EverFE}

To carry out this work, a finite element computational software was used in order to model the typical sections of rigid pavement structures. EverFE is a computational 3D finite element analysis tool that allows to simulate the response of rigid concrete pavement systems to the loads imposed by traffic as well as environmental effects. EverFE presents a highly interactive graphical user interface where structures can be modeled and the results can be visualized graphically or numerically, being able to visualize stresses and displacements in paving slabs and granular layers, as well as internal forces and moments of the load in dowels [7]. The software uses five elements to simulate JPCP systems: a) a 20-node quadratic element that has three deflection components at each node used for the slab, elastic base and subbase layer, (b) an 8-node plane quadratic element model the dense liquid foundation below the lowermost elastic layer, c) a 16-node quadratic interface element implements both aggregate interlocking joint and shear transfer at the slab-base interface, d) a flexural element and 3node embedment coupled with conventional 2-node shear beams are used to model the dowel bars and the tie bars and e) for the modeling of the subgrade, dense liquids with and without vertical support stress are used [8].

The procedure to carry out the modeling in the program consists of entering the data in six tabs to define all the properties of the model. The first tab refers to the geometry of the model and there the data of the dimensions of the slabs, the number of slabs, the number of layers and their thicknesses are entered. In the second tab, the properties of the materials that make up the concrete slab, the dowels (if applicable) and the granular layers are defined, requiring basic data such as modulus of elasticity, density and poisson's ratio, as well as the properties characteristics of the bars and the subgrade. The third tab, governs the loads, for which the program is quite generous, allowing to include a large number of loads and in different configurations, with which you can model simple wheels, single axles with wheel, single axles with double wheel, tandem and tridem axles, as well as other specials. The next two tabs refer to the dowels and the transfer of load by interlocking of aggregates. There, the characteristics and location of the dowels are defined, as well as the shear properties of the concrete, in the case in which there are no dowels. Finally, there is the meshing tab, which is chosen according to the dimensions of the structure and the precision of the results [9] [10].

For the present work, the typical pavement section modeled with the software consisted of a rigid pavement layer (tread layer), a granular base layer, a selected material layer (subgrade improvement) and the subgrade. The aforementioned structure was evaluated for different thicknesses of the pavement slab and a bearing capacity of the subgrade, in accordance with the characteristic soils present in the study area. For the design transit, the maximum legal loads stipulated by the Ministry of Transport of Colombia [11] were taken and a contact pressure of $5.6 \mathrm{~kg} / \mathrm{cm}^{2}$ was used for all cases. The thickness of the pavement layers varied between 100 and $300 \mathrm{~mm}$ and load transfer segments were arranged as stipulated in the concrete pavement design manual for roads with low, medium and high volumes of traffic [11]. The concrete slab was supported in all cases, on a $200 \mathrm{~mm}$ thick granular base, whose properties were not varied in the modeling. In the case of the subgrade, one level of bearing capacity was considered.

\section{II.II Finite element modeling and design variables}

The modeling of the structure consisted of a two-lane road, made up of three sections of slabs on each side. The selected slabs were square, with plan dimensions of $3.6 \mathrm{~m} \times 3.6 \mathrm{~m}$ and the axles with the proposed loads were located in the central slab offset towards the lateral edge of the slab. In figure 1 the modeled structures can be observed in detail and the particular case for the $20 \mathrm{~cm}$ thick slab is presented.

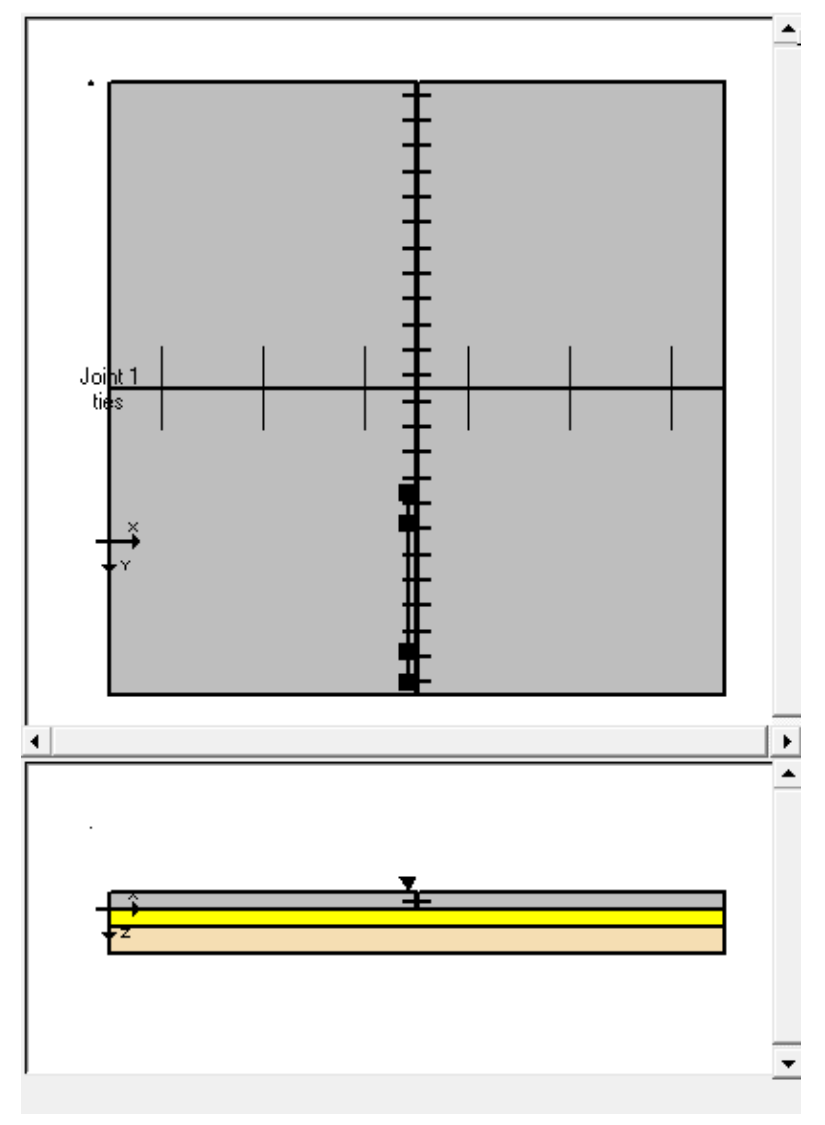

Fig. 1. Modeled pavement structures

The mesh used for the analysis of the structures was 12 elements for each plate of the slab, which results in a division every $30 \mathrm{~cm}$ in plan. The boundary conditions of the model were chosen to minimize the influence of the stress distribution. The materials and properties used in the modeling can be consulted in Table 1.

In the case of the dowels, these were arranged every $30 \mathrm{~cm}$ and their properties are shown in Table 2.

The traffic loads were selected, taking into account the four types of characteristic axes of the commercial vehicles that travel along the country's roads, with their respective maximum legal loads, in accordance with the requirements established in resolution 1782 of 2009, where the limits of weights and dimensions are adopted by road transport vehicles, for their normal operation in the Colombian road network. The selected axles are detailed in Fig. 2. 
International Journal of Engineering Research and Technology. ISSN 0974-3154, Volume 13, Number 11 (2020), pp. 3907-3912

○ International Research Publication House. https://dx.doi.org/10.37624/IJERT/13.11.2020.3907-3912

Table 1. Pavement material properties

\begin{tabular}{cccc}
\hline Material & Rigid Concrete $(\mathbf{m m})$ & Base $(\mathbf{m m})$ & Selected Soils $(\mathbf{m m})$ \\
\hline Tickness & $100,150,200,250,300$ & 200 & 300 \\
Density $\left(\mathrm{Kg} / \mathrm{m}^{3}\right)$ & 2400 & 2150 & 1900 \\
Elastic Modulus $(\mathrm{Mpa})$ & 30000 & 200 & 50 \\
Poisson's ratio (u) & 0.20 & 0.40 & 0.45 \\
\hline
\end{tabular}

Table 2. Recommendations for the selection of dowels

\begin{tabular}{cccc}
\hline Pavement Thickness $(\mathbf{m m})$ & Dowel Diameter $(\mathbf{m m})$ & Dowel Lenght $\mathbf{( m m})$ & Dowel Separation $(\mathbf{m m})$ \\
\hline 100 & 13 & 250 & 300 \\
150 & 19 & 350 & 300 \\
200 & 25 & 350 & 300 \\
250 & 32 & 450 & 300 \\
300 & 38 & 500 & 300 \\
\hline
\end{tabular}

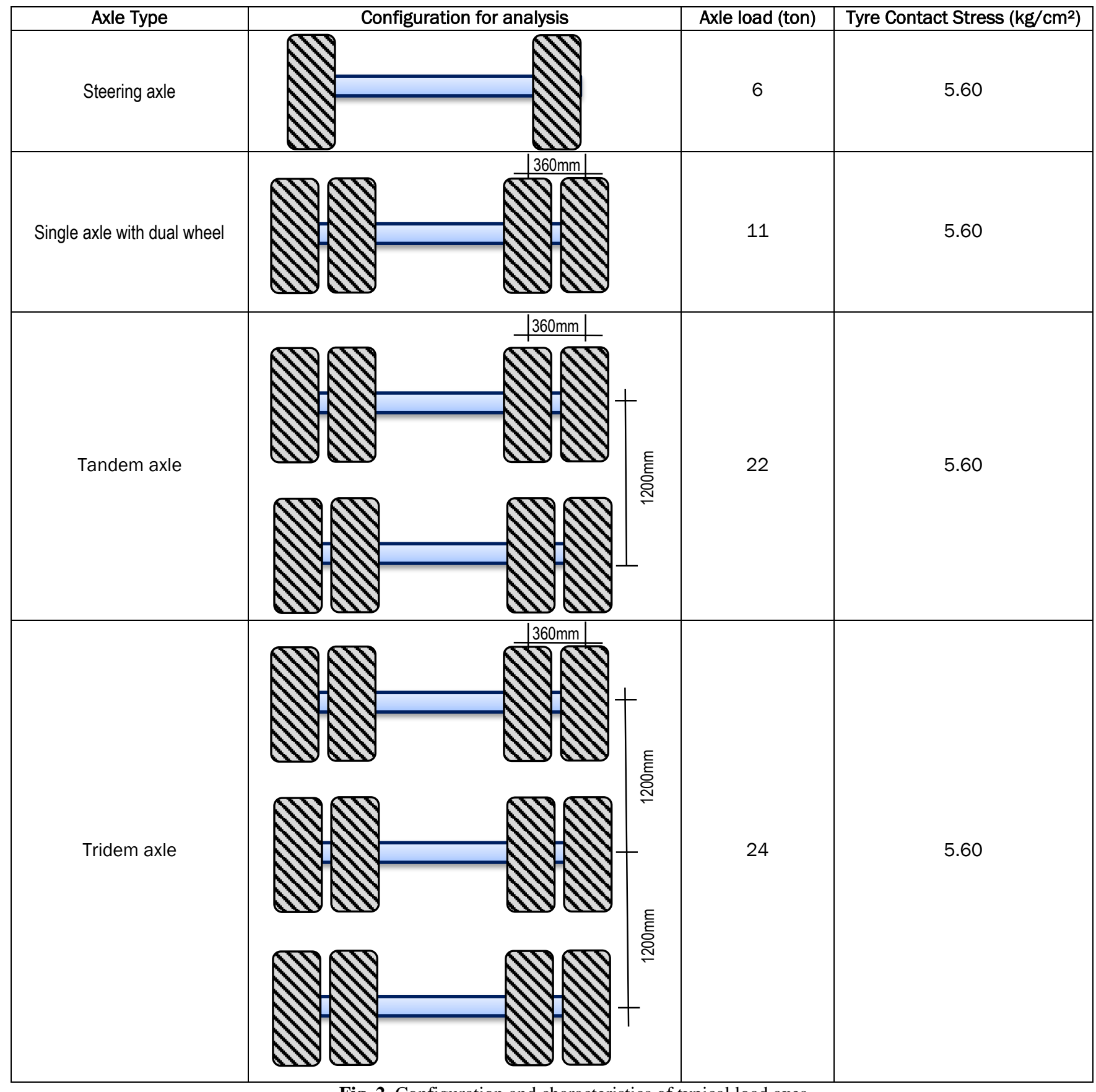

Fig. 2. Configuration and characteristics of typical load axes 
International Journal of Engineering Research and Technology. ISSN 0974-3154, Volume 13, Number 11 (2020), pp. 3907-3912

(C) International Research Publication House. https://dx.doi.org/10.37624/IJERT/13.11.2020.3907-3912

\section{RESULTS}

Based on the results obtained in the modeling of pavement structures in the EverFE program, the following results were obtained.
The modeled slab systems are shown in Fig. 3. These are made up of four slabs, being able to observe the displacements in the $\mathrm{Z}$ axis caused by the four types of axles analyzed, thus appreciating the typical deformations generated in the slabs.

a) Steering axle

b) Single axle with dual wheel
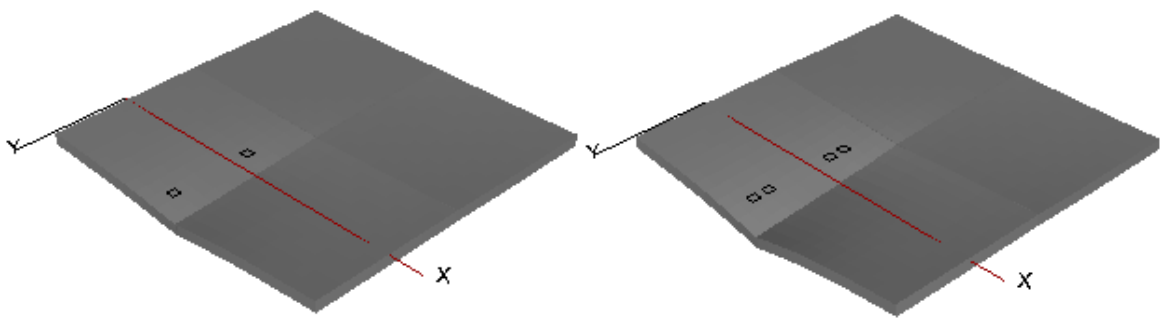

c) Tamdem axle

d) Tridem axle
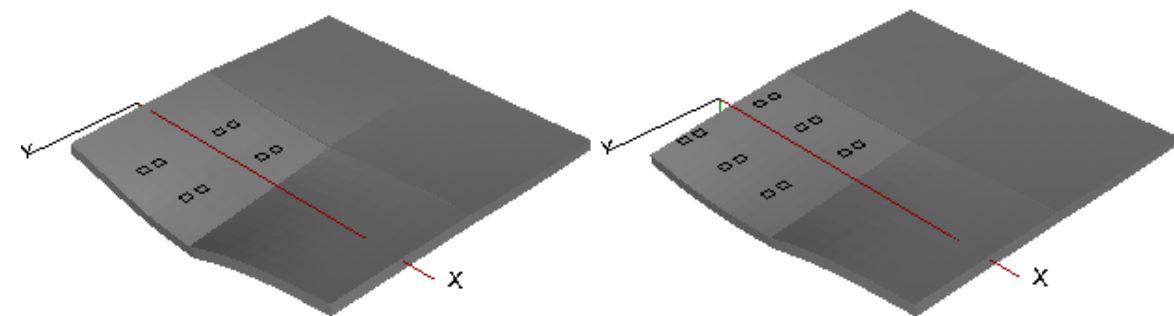

Fig. 3. Typical displacements of the modeled systems under the proposed loads

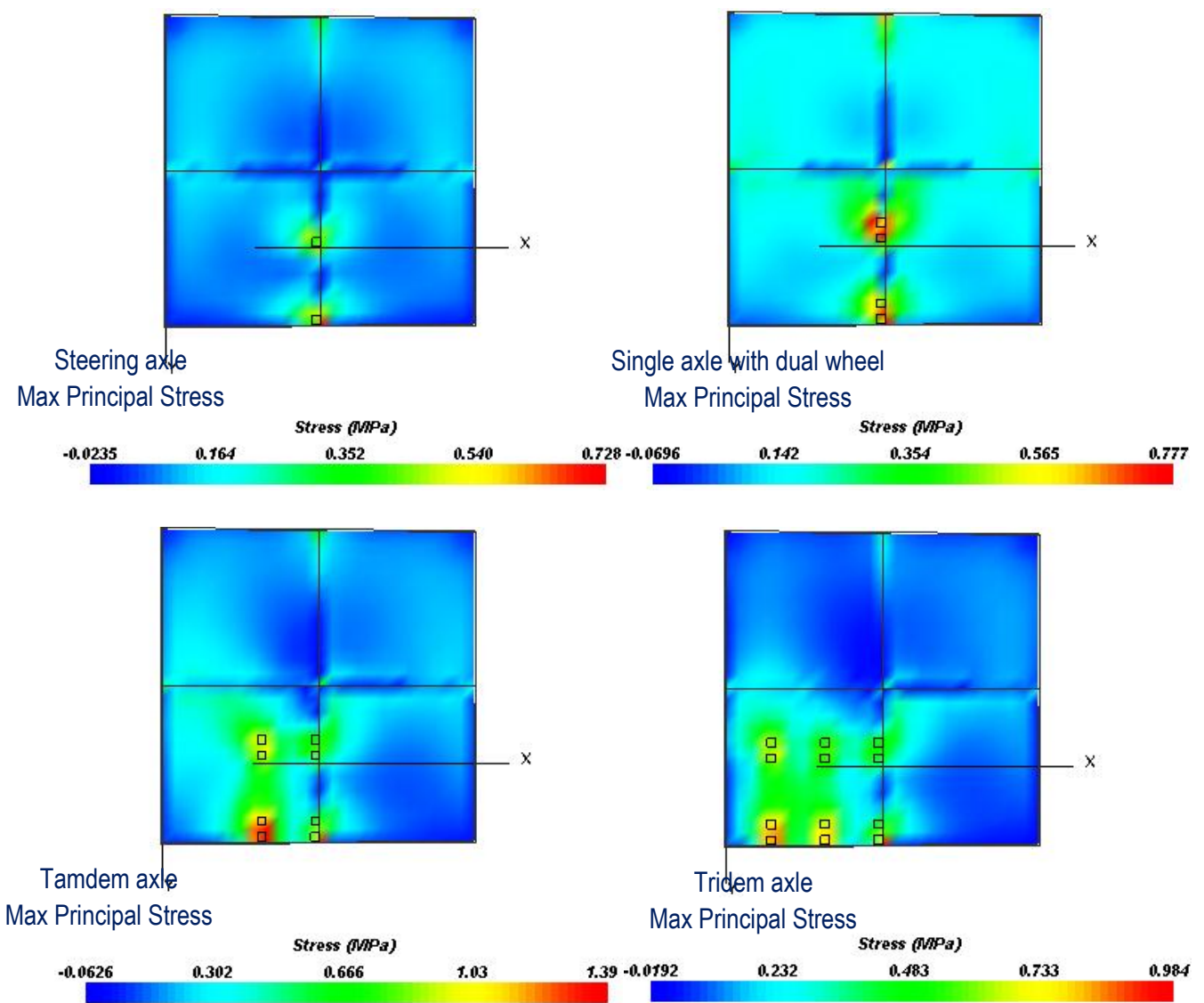

Fig. 4. Distribution of maximum principal stresses in the paving slabs. 
International Journal of Engineering Research and Technology. ISSN 0974-3154, Volume 13, Number 11 (2020), pp. 3907-3912

(C) International Research Publication House. https://dx.doi.org/10.37624/IJERT/13.11.2020.3907-3912

Fig. 4 presents the results of the main maximum stresses (in the lower fiber of the concrete slab) for the pavement slabs, for each of the axes analyzed. In the diagrams, the distribution of stresses, as well as their magnitude, can be graphically observed, revealing the types of axles that generate the greatest stresses on the structures. The case shown corresponds to that of the $25 \mathrm{~cm}$ thick slab. For the case of the other thicknesses considered in the analysis, the behavior is similar.
Fig. 5 shows a comparison of the maximum stresses produced in the evaluated structures, as a function of the slab thicknesses and the type of load axle.

In Fig. 6 a comparison of the displacements in $\mathrm{Z}$ is presented as a function of the different thicknesses of the paving slab and the types of load axles.

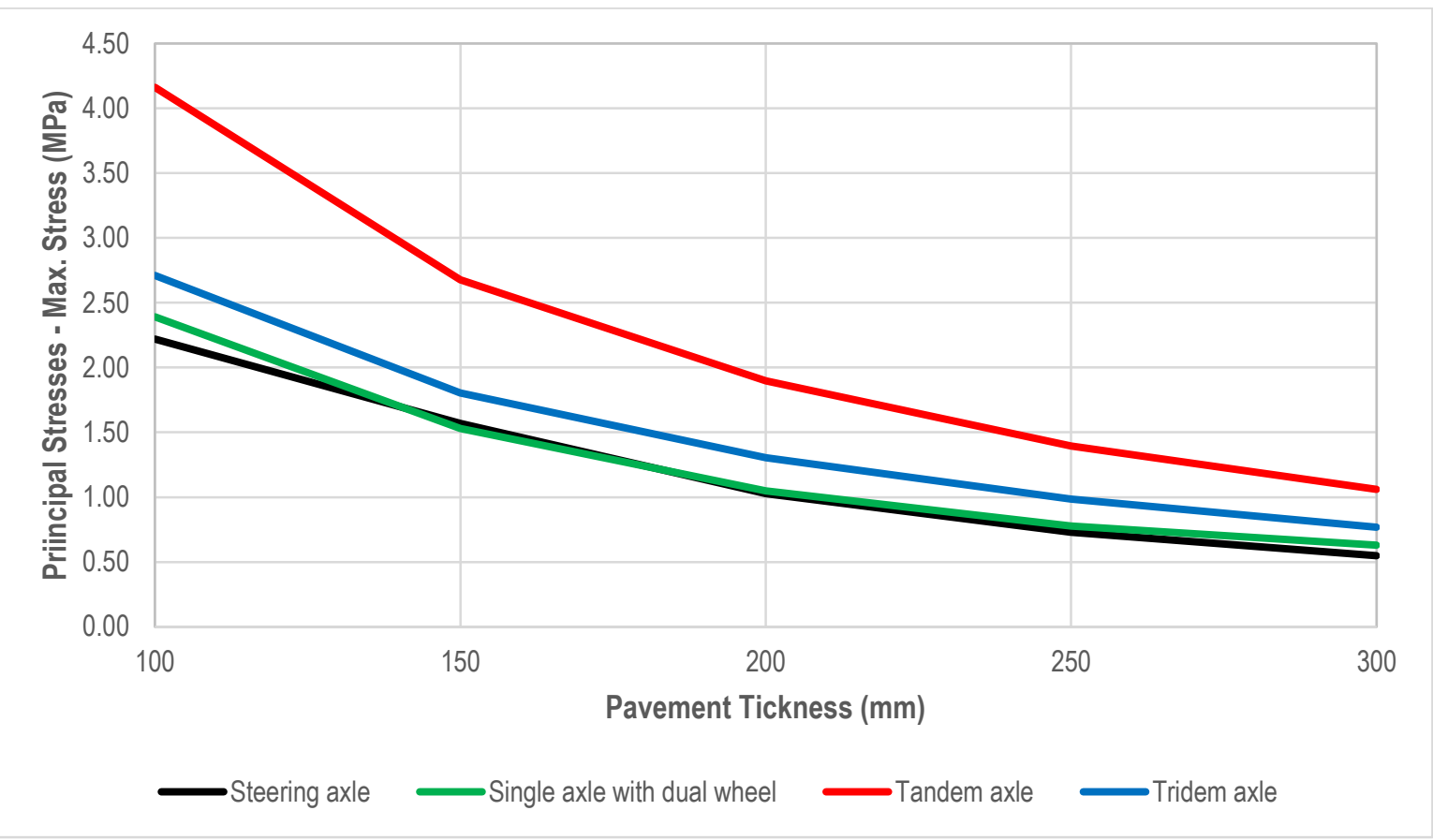

Fig. 5. Principal maximum stresses produced by the different axles

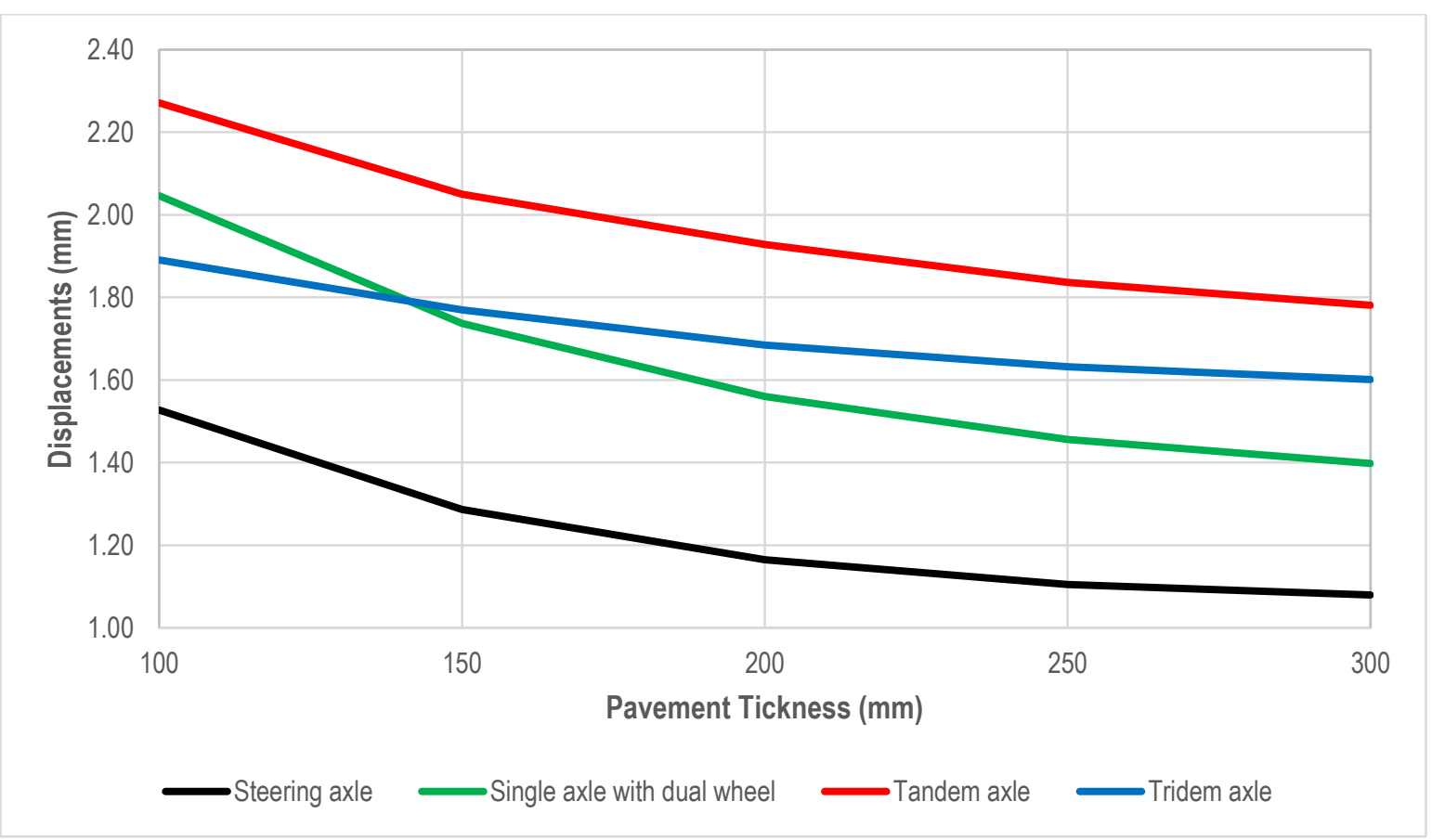

Fig. 6. Displacements in Z produced by the different axles 


\section{CONCLUSIONS}

From the results obtained from the modeling of rigid pavement structures by the finite element method using the EverFE software, it can be concluded:

The stresses produced in the pavements by the load axes depend on the magnitude and configuration of the axes. In the case of steering and single with double wheel axles, these apply to the pavement slabs with magnitudes of efforts that are very close to each other, even though their maximum legal loads allowed are very different. With regard to the tridem axles, in which the highest permissible load is presented, they manage to distribute the loads to the pavement through a greater contact area, having a configuration of 12 wheels, in such a way that the transmitted forces they are relatively smaller than those generated by tandem axles. In the case of tandem axles, these are the ones that generate the greatest stresses on the pavement slabs, due to the fact that the loads are concentrated through smaller contact areas than that of the tridem axles.

For all the evaluated axles, it was observed that as the thickness increases, the stresses generated in the slabs decrease. However, it should be noted that the stress reduction rate tends to decrease, as the thickness of the pavement slab increases.

For the case of the displacements in $\mathrm{Z}$, it was observed that the steering, single with double wheel and tandem axles, present a very similar behavior in their displacement vs Thickness curves; However, in the case of tandem axes, these generate displacement magnitudes of the order of 50 to $70 \%$ greater than those generated by steering axles; whereas the single axles with double wheels, present intermediate values. In the case of tridem axles, these present a flatter curve and with values close to those generated by single alxe with double wheel.

\section{ACKNOWLEDGMENTS}

The authors thank the engineer Edilberto Elias Contreras Sierra for the contributions made in the development of the manuscript.

\section{REFERENCES}

[1] Londoño C, Alvarez J, Manual de diseño de pavimentos de concreto: para vías con bajos, medios y altos volúmenes de tránsito, Instituto Colombiano de Productores de Cemento (ICPC), Medellín, 2008.

[2] Saucedo A, Concreto hidráulico permeable, una alternativa para la recarga de los mantos acuíferos del Valle de México, Tesis de pregrado, Universidad Nacional Autónoma de México, México, 2010.

[3] Hernández F, Badía A, Tejeda E, Serrano L, Estado del Conocimiento en la Modelación de Pavimentos Rígidos, La Habana, Cuba, 2012.

[4] Rens L, Ghafari S, Alte-Teigeler T, Bollé M, Vrieze J, Kramer W, Guide for design of "Jointed Plain Concrete Pavements". European Concrete Paving Association. Brussels, 2020.2 Doi: https://doi.org/10.13140/RG.2.2.26141.46561

[5] Huang YH, Pavement Analysis and design. Second Edition. Prentice Hall. USA, 2003.

[6] Vásquez L, Salgado J. Método Alternativo de Diseño de Espesores para Pavimentos de Concreto Simple con Juntas y Dovelas sobre Fundación Sólida Elástica Lineal. Simposio Colombiano sobre Ingenieria de Pavimetnos. Universidad EAFIT, 2019.

[7] Davids WG, EverFE Theory Manual, University of Maine, Civil and Environmental Engineering Department, United States of American, 2003.

[8] Sunghwan K, Halil C, Kasthurirangan G, Finite element modeling of environmental effects on rigid pavement deformation. Frontiers of Structural and Civil Engineering, 8(2) pp.101-114, $2014 . \quad$ Doi: https://doi.org/10.1007/s11709-014-0254-x

[9] Davids WG, Turkiyyah GM, Mahoney JP, EverFE: Rigid Pavement Three-Dimensional Finite Element Analysis Tool, Transportation Research Record 1629, TRB, National Research Council, United States of American, pp. 41-49, 1998. Doi: https://doi.org/10.3141/1629-06

[10] Davids WG, Wang ZM, Turkiyyah G, Mahoney J, Bush D, Three-Dimensional Finite Element Analysis of Jointed Plain Concrete Pavement with EverFE2.2." Transportation Research Record 1853: Journal of the Transportation Research Board, TRB, National Research Council, United States of American, pp. 92-99, 2003. Doi: https://doi.org/10.3141/1853-11

[11]Resolución 1782 del 8 de Mayo 2009, Ministerio de Transporte, Colombia, 2009. 